\title{
СПЕЦИФІКА ПОНЯТТЯ “КОЛЕКТИВНА СУБ'СКТНІСТЬ” У ВІТЧИЗНЯНІЙ ТА ПОСТРАДЯНСЬКІЙ СОЦІАЛЬНІЙ ПСИХОЛОГІї
}

Висвітлюється проблематика розуміння та розроблення понять “колективний суб'єкт” і “колективна суб'єктність” у сучасному вітчизняному та пострадянському соціально-психологічних дискурсах. Звертається увага на незбіг проблемного загалу, який слугує контекстом для аналізу понять “колективний суб'єкт” і “колективна суб'єктність”. Показано, що для вітчизняного соціальнопсихологічного простору таким загалом є проблема співвідношення індивідуального і соціального в їхньому впливі на постання колективного суб'єкта, тоді як для простору пострадянського проблемний загал формується проблематикою загальнопсихологічної теорії діяльності та проблемою суб'єкта діяльності зокрема. Також зауважено, що такий проблемний загал впливає і на побудову методологічних засад як вихідних умов, що пред'являються щодо групи з огляду на можливість ії розгляду як колективного суб'єкта. Наголошено, що для вітчизняного дискурсу характерним $є$ акцент на розробленні засад колективності, тоді як в пострадянському дискурсі перевага надається суб'єктності. Зауважено, що означені проблемні загали замикаються на більш широку проблематику пояснення виникнення “динаміки цілого”, що не зводиться до сукупності своїх частин. Встановлено, що розроблені критерії виокремлення колективного суб'єкта унеможливлюють розуміння суспільного волонтерського руху як колективного суб'єкта. Зроблено висновок, що проблема знімається, якщо припустити, що визначальним для специфіки колективної суб'єктності суспільного волонтерського руху є інше співвідношення ваги критеріальних ознак. Сформульовано засади виокремлення специфіки колективної суб'єктності суспільного волонтерського руху та обгрунтовано можливість такого виокремлення шляхом розроблення конструкта “спільність".

Ключові слова: волонтерство, волонтерство АТО, суспільний рух, колективний суб'єкт, колективна суб'єктність, спільність, мотивація.

H. V. Koval

\section{THE SPECIFICITY OF "COLLECTIVE SUBJECT" CONCEPT IN UKRAINIAN AND POST-SOVIET SOCIAL PSYCHOLOGY}

It is considered the problem of understanding and development of "collective subject" and "collective subjectivity" concepts in contemporary Ukrainian and postSoviet socio-psychological discourses. Attention is drawn to the mismatch of the problem context which serves as a framework for the analysis of "collective subject" and "collective subjectivity" concepts. It is shown that for the Ukrainian socio-psychological space this general context remains the problem of interrelation between "individual" and "social" in their influence on the collective subject posture; while for the postSoviet space the problem context is forming by the general-psychological theory of activity and, particularly, by the problem of activity's subject. It is also noted that such a general context affects the construction of methodological foundations as the 
conditions which are required to a group as a collective subject. It is emphasized that in Ukrainian discourse the accent is on the development of collectivity principles, while in post-Soviet discourse the preference is given to subjectivity. It is noted that these general contexts are relevant to a wider problematic context of an explanation of the "dynamics of the whole" emergence, which is not limited to a set of its parts. It is established that the developed criteria to define "collective subject" concept make it impossible to understand the volunteering movement as a collective subject. It is made a conclusion that the problem is removed assuming that the determining factor for the collective subjectivity's specificity of volunteering movement is another interrelation of criterion signs. There are formulated the foundations for the collective subjectivity of volunteering movement specificity's selection and substantiated the possibility of such selection through the development of "commonality" concept.

Key words: volunteering, ATO volunteering, social movement, collective subject, collective subjectivity, commonality, motivation.

Постановка проблеми. Актуальність розвідки постає в контексті дослідження суспільного волонтерського руху (далі - СВР), що ставить за мету надання допомоги учасникам та постраждалим від збройного конфлікту, спричиненого агресією РФ. При цьому СВР як предмет соціально-психологічного аналізу знаходить своє місце в межах таксономії великих організованих груп завдяки виокремленню та обгрунтуванню як критерію класифікації поняття "соціальне завдання" - сукупності умов та цілей, релевантних діям та операціям як підструктурам діяльності. За такого розуміння відкритим залишається питання чинників, які пов'язують індивідів у спільноту і, відповідно, релевантні мотиваційній підструктурі діяльності. Позиціонування СВР як великої організованої групи також зумовлює його розуміння як суб'єкта діяльності. Отож ідеться про необхідність виокремлення та розкриття специфіки колективної суб'єктності СВР, адже доцільно припустити, що саме специфіка колективної суб'єктності, іiі параметри та умови набуття зумовлюють соціально-психологічні особливості мотиваційної сфери СВР як великої групи. Обгрунтування цього припущення потребує актуалізації наявних у сучасному соціально-психологічному дискурсі критеріїв, параметрів та принципів виокремлення колективного суб’єкта як сукупності умов, що уможливлюють розуміння тієї або іншої групи як цілісної одиниці.

Аналіз останніх досліджень і публікацій, виокремлення не вирішених раніше частин загальної проблеми. Поняття “колективний суб'єкт” як категорія соціально-психологічного дискурсу активно розробляється на теренах як вітчизняного (В. Васютинський, П. Горностай, В. Москаленко, В. Татенко, В. Третьяченко та ін.), так і пострадянського (А. Брушлинский, К. Гайдар, А. Журавльов, О. Мірошниченко та ін.) наукових просторів у межах загальнопсихологічного суб'єктного підходу (С. Рубінштейн, А. Брушлинський, К. Абульханова-Славська, В. Татенко та ін.). Утім, специфіка поняття “колективний суб'єкт” та похідного від 
нього поняття “колективна суб'єктність” обгрунтовується в межах дещо різних проблемних загалів. Тому постає необхідність експлікації цих загалів, від яких безпосередньо залежить можливість виокремлення специфіки колективної суб'єктності СВР. Адже специфіка проблемного загалу актуалізує принципово різні вихідні умови щодо оцінювання можливості розуміти певну групу як колективного суб'єкта та цілісну “одиницю” власної активності.

Мета статті полягає в рефлексії та висвітленні наявних у сучасній вітчизняній та пострадянській соціальній психології методологічних принципів вивчення категорії “колективний суб'єкт” та формулюванні засад виокремлення специфіки колективної суб'єктності СВР.

Виклад основного матеріалу дослідження. Підходи вітчизняних авторів щодо базової проблеми, що становить загал, у межах якого розробляються поняття колективного суб'єкта, у цілому збігаються. Узагальнено цю проблему можна означити як проблему співвідношення індивіда і суспільства, точніше - співвідношення індивідуального і соціального в обумовленні колективної суб'єктності. Так, В. Татенко, обгрунтовуючи суб'єктно-вчинковий підхід у соціально-психологічному вимірі, наголошує на існуванні двох напрямків - соціально та індивідуально орієнтованих, а також намагається їх поєднати, зокрема через категорію інтерсуб'єктивності [1, с. 91-92]. Доречний спосіб поєднання позиціонується як діалектичне взаємообумовлення індивідуального i позаіндивідуального в людині як цілісному суб'єкті життєдіяльності [там само, с. 97].

В. Васютинський актуаліє означену проблему, грунтуючись на сукупності принципів процесу постання та функціонування колективного суб'єкта. Визнання первинності існування індивідуального суб'єкта, де колективний суб'єкт є моментом взаємодії, або ж, навпаки, первинності колективного суб'єкта, що існує в просторі інтерперсональності і не залежить від волі індивідів, дає змогу конкретизувати проблему [2, c. 24-25]. Остання розв'язується як позиціонування взаємообумовленості їхнього впливу з тяжінням до виокремлення важливості індивідуальної складової [там само, с. 34].

В. Москаленко, розбудовуючи засади дослідження економічної соціалізації суб'єкта, занурює проблему становлення особистості як суб'єкта економічної соціалізації в поле парадигми соціального конструктивізму. Дослідниця наголошує на інтегративності поняття “суб'єкт”, на базі якого можна означити спільне для індивіда і групи [3, с. 25], i, спираючись на термін “вибір” [там само, с. 29], обгрунтовує суб'єктність як властивість суб'єкта (індивіда або групи) бути джерелом конструювання та перетворення соціальної реальності, що зумовлено вибірковим ставленням до навколишнього середовища, яке внаслідок такого ставлення перетворюється на простір [там само, с. 31]. Отже, проблема 
взаємозв'язку індивідуальності і суспільства описується термінами виявлення суб'єкта соціальних явищ (впритул до аналізу підстав постановки питання щодо суб'єкта історичного процесу) та розв'язується завдяки визнанню вагомої ролі ціннісно-мотиваційних чинників у становленні характеристик суб'єктності. Тобто розв'язок проблеми тяжіє до розкриття насамперед впливу індивідуальності на суспільство.

У світлі означеного вище хотіли б наголосити на тому, що окремим напрямом “'заглиблення” в проблематику суб'єктності є розкриття суб’єктних характеристик ціннісно-мотиваційних утворень як чинників впливу на індивідуальний чи груповий суб'єкт і, власне, з'ясування статусу цих утворень у межах означених суб'єктів як складових їхньої суб'єктності. Адже виникає певна суперечність у розумінні такого статусу, оскільки означення характеристик суб'єктності для ціннісномотиваційного утворення спонукає позиціонувати його як суб'єкта специфічного впливу, унаслідок чого постає необхідність виокремлювати суб'єкта в суб'єкті. У межах загальнопсихологічної категорії “суб'єкт” означена проблематика потребує окремого напряму аналізу. Так, О. Лукасевич провела аналіз взаємовідношення понять “особистість" i “суб'єкт" на підставі означення взаємосуперечливих позицій щодо розуміння їх співвідношення. Одна з альтернатив базується на підході Б. Ананьєва, який обстоює статус суб'єкта як окремої підструктури в загальній структурі індивідуальності поряд з особистістю та індивідом. Протилежною альтернативою є розуміння суб'єкта як інтегральної властивості людини вміщувати в собі всю сукупність системних ознак індивідуальності, що реалізовано в підході А. Брушлинського, К. Абульханової-Славської та їхніх послідовників [4, с. 44].

Отож постає необхідність додаткового аналізу підстав та можливостей означення характеристик суб'єктності для того або іншого “психологічного” утворення, чи то цінність, норма, чи то особистість, індивідуальність, чи то група, спільнота, що потребує, зрештою, окремої розвідки. Наразі ж акцентована проблематика взаємозв'язку понять “суб'єкт” і “особистість” дає змогу перейти до означення специфіки розвитку проблеми колективного суб'єкта в дискурсі пострадянського простору. Тут, як відомо, категорія “колективний суб'єкт” розробляється в межах суб'єктно-діяльнісного підходу С. Рубінштейна. Теоретикометодологічні настанови цього підходу представлено в доробку А. Брушлинського, К. Альбуханової-Славської, А. Журавльова та ін. [5; 6]. Обгрунтування специфіки суб'єктно-діяльнісного підходу базується на порівняльному аналізі діяльнісного підходу в інтерпретації О. Леонтьєва. Так, А. Журавльов, розкриваючи сучасні уявлення щодо розуміння колективного суб'єкта, спирається на аналіз філософсько-психологічних ідей С. Рубінштейна, де принциповим моментом є позиціонування як суб'єкта діяльності саме людини, а не особистості та есплікується розуміння соціальної сутності людини як первісної їі ознаки [6, с. 72]. 
Означений підхід знаходить свою дальшу реалізацію насамперед у контексті розвитку проблематики колективної суб'єктності на основі аналізу малої групи, зокрема в доробку К. Гайдар і О. Мірошниченко. Зокрема, К. Гайдар обгрунтовує суб'єктний підхід як окрему методологію дослідження малої групи та виокремлює проблему розвитку такої групи [7]. На основі критеріїв колективного суб'єкта вибудовуються емпіричні дослідження, мета яких - виявлення рівнів та етапів розвитку малої групи як носія колективної суб'єктності. За рівень розвитку при цьому взято такі типи колективної суб'єктності, як потенційна, реальна та рефлексивна в їхніх проявах у різних видах активності групи - пізнанні, спілкуванні, сумісній діяльності, взаємовідносинах тощо [там само, с. 19-21]. Нерівномірність вираження колективної суб'єктності до певної міри обгрунтовує постановку О. Мірошниченко проблеми щодо необхідності дослідження актуалізації групового суб'єкта в різних умовах його (суб'єкта) життєдіяльності [8].

Як бачимо, на пострадянському просторі логіка розвитку суб'єктного підходу до аналізу малої групи до певної міри уточнює, але водночас і розмиває “строгість” поняття. Адже якщо розуміти малу групу як колективний суб'єкт своєї активності, тобто власне активності, що розгортається від групи як цілісної одиниці (тобто колективного суб’єкта), то питання щодо актуалізації такої одиниці за замовчуванням має містити в собі припущення, що мала група як мала група може існувати в такому статусі як номінально (потенційно), так і реально. Тобто якщо властивості групової суб'єктності є, з одного боку, засадничими для виокремлення малої групи як такої, а $з$ другого - можуть бути виражені нерівномірно, то постає необхідність поряд з умовами життєдіяльності як чинників актуалізації групи-як-суб'єкта (чинники, що створюють групу, i чинники, що підтримують ії як групу) також виокремлювати i їхній вплив на часовий аспект існування групи-як-суб'єкта, ії тривалість, інтенсивність, інші аспекти гетерохронії (характер прояву суб'єктності пульсація, рівномірність, спалах тощо; характер і продукт групової активності залежно від часу розгортання та прояву тощо).

Отже, базова проблема, яка визначає загал аналізу категорії “колективний суб'єкт”, є складником проблеми суб'єкта діяльності та розробляється переважно у зв'язку з проблематикою малої групи. Існування різнорідних загалів позначилося також і на підходах до виокремлення методологічних засад розбудови сукупності вихідних вимог, які пред'являються до певного об'єкта соціально-психологічної таксономії, коли його оцінюють з огляду на можливості розуміння як колективного суб'єкта.

В. Васютинський запропонував та обгрунтував як такі вихідні вимоги систему принципів постання колективного суб'єкта. При цьому базовою проблематикою, яка зумовлює специфіку постання колективної 
суб'єктності, є необхідність онтологічної однозначності виокремлення матеріального носія даної суб'єктності [9, с. 14]. Проблематика ж такого виокремлення увиразнюється шляхом означення переважної представленості колективної суб’єктності у вигляді функції, через яку вона постає більш питомо, аніж через структурні свої компоненти [там само, c. 15]. Власне функціональна постава колективного суб'єкта уможливлюється через обгрунтування доцільності виокремлення четвертої, поміж традиційно усталених трьох, феноменологічної сторони спілкування [там само, с. 13-14]. Саме феноменологічна сторона спілкування увиразнює собою певний результат взаємодії (інтеракції) суб'єктів, що постає, насамперед та головно, у вигляді спільно утвореного простору взаємодії - інтерсуб'єктивного феноменологічного простору, в якому можуть бути втілені об’єкти спільного творення. Цей простір є основою, фундаментом колективної суб'єктності в площинах іiі постання та функціонування. Власне, сукупність із п'яти означених принципів - інтеракційності, символічного опосередкування, колективної феноменологічності, об'єктної втіленості, інтерсуб'єктивності [2, с. 24] - покликана увиразнити психологічний зміст феноменологічної сторони спілкування як базису колективної суб'єктності.

Отже, акцент суттєво зміщено на можливі умови творення не так суб'єктності, як колективності, яка увиразнюється через проблематику спілкування, а не діяльності. Вагомим складником колективності, власне феноменологічно даним іiі аспектом, є спільність як така: спільна взаємодія у символічно опосередкованому спільному просторі, як основа спільної дійсності, приводить до спільно створеного об'єктного результату, релевантного груповому суб'єктові його творення загалом, а не індивідуальним складникам суб'єкта.

Як уже зазначалося, розроблені А. Журавльовим критерії, що пред'являються до групи як колективного суб'єкта, базуються на проблематиці діяльності, де власне спільна діяльність є генеральним критерієм судження про певну сукупність як про колективний суб'єкт цієї діяльності [6]. Зокрема, запропоновано такі критерії, як взаємопов'язаність і взаємозалежність індивідів у групі; здатність групи реалізувати різноманітні форми сумісної активності; здатність групи до саморефлексії [там само, с. 73-76]. Припускається, що ці критерії можуть водночас бути і параметрами колективного суб'єкта. Те, що вони можуть бути виражені різною мірою, дає підстави говорити про різні типи суб'єктності - потенційний, реальний та рефлексивний [там само, c. $77-78]$.

Застосування розглянутих критеріїв до СВР відбиває певну проблематичність їх застосування саме щодо цієї великої групи. Адже на рівні очевидності зрозуміло, що колективна форма активності СВР реалізовується у формі індивідуальної суб’єктності на рівні міжособової 
взаємодії між волонтером і реципієнтом. А це суперечить "генеральному" критерію колективної суб'єктності та унеможливлює розгляд СВР як колективного суб'єкта (якщо тільки не розпорошувати поняття спільної індивідуальної діяльності до меж усього суспільства як середовища волонтерської діяльності).

Це означає, що постає певна проблема, коли йдеться про можливість тлумачення СВР як колективного суб'єкта (одиниці) діяльності з надання допомоги. Оскільки в такій діяльності активність більше ніж реальна, то немає й підстав говорити про потенційну суб'єктність цієї форми колективного суб'єкта. Утім, якщо припустити, що індивідуальна суб'єктність є однією із форм реалізації колективної суб'єктності, то проблема щодо можливості розуміння СВР як цілісної одиниці (групи) переміститься в площину першої ознаки. Тобто можемо припустити, що специфіка взаємозв'язків між елементами суспільного руху (волонтерами) є системотвірним фактором та обумовлює набуття ознак колективної суб'єктності цією формою суспільного явища. Виходить, колективна суб'єктність СВР обумовлена іншим співвідношенням параметрів колективної суб'єктності, аніж їх необхідне співвідношення для колективної суб'єктності інших таксономічних одиниць.

У світлі висловленого припущення бачимо, що запропоновані А. Журавльовим параметри колективної суб'єктності постають як критеріальні ознаки виокремлення колективного суб'єкта, але не зберігають статус параметрів колективного суб'єкта. Натомість розкриваються як параметри, що характеризують чинники колективної суб'єктності. При цьому в межах першої критеріальної ознаки йдеться про чинники колективної суб'єктності, які впливають на її постання, оскільки покликані розкрити специфіку взаємозв'язків між членами спільноти як наслідок впливу цих чинників. Водночас у межах другої ознаки йдеться радше про характеристики процесу безпосереднього впливу чинників, що відображено в першій ознаці. Тобто розкривається сукупність можливих механізмів, завдяки реалізації яких досягається умова першого критерію взаємозв'язок. При цьому третя ознака дає змогу виявити ті процеси, на основі яких також реалізується механізм впливу чинників, але вже не на постання, а на збереження колективної суб'єктності. Адже, хотіли б звернути увагу, змістовий складник третьої ознаки в ії постуляції А. Журавльовим [6, с. 74] - це явище, яке стає можливим лише завдяки досвіду реалізації групою певної спільної активності.

Подальший рух у напрямі з'ясування специфіки колективної суб'єктності СВР припускає конкретизацію тих змінних, що виступають у ролі чинників та впливають на колективну суб'єктність. Тобто можна зробити певне схематичне узагальнення засад виокремлення специфіки колективної суб'єктності СВР, яка складається з низки нетотожних елементів, а саме: механізму утворення колективної суб'єктності як 
сукупності чинників та процесів реалізації їхнього впливу; власне колективної суб'єктності в ії специфіці; впливу колективної суб'єктності на активність (діяльність) групового/ індивідуального суб'єкта. 3 огляду на це можемо зробити висновок: щодо діяльності або іншої активності суб'єкта колективна суб'єктність сама є чинником - по суті, мотивом діяльності, тобто дієвою (дійсною) причиною.

Також слід зауважити, що переміщення акценту в площину першої критеріальної ознаки повертає проблематику колективного суб'єкта в лоно того проблемного загалу, який характерний для аналізу колективної суб'єктності в межах вітчизняного дискурсу. Утім, як бачимо, незважаючи на специфіку різних загалів щодо висунення вихідних вимог до колективного суб'єкта, ці загали збігаються в проблемі виникнення “динаміки цілого”, що не зводиться до сукупності своїх частин [10, c. 167]. Оскільки вітчизняний загал зорієнтований на вирішення проблематики колективного суб'єкта за рахунок пояснення підвалин спершу колективності, то колективність як така стає характеристикою цілого, що робить його неподільною одиницею. При цьому, як зазначалося вище, колективність у своїй феноменологічній даності постає як спільність. Отож можна припустити, що спільність як характеристика зв'язку між індивідуальними суб'єктами, що зумовлює цілісність суб'єкта колективного, щодо його (колективного суб'єкта) активності має проявляти себе в ній як чинник. Тобто, якщо вдатися до образної метафори, зв'язок з іншим є мотивом у буквальному значенні двигуна, який володіє потугою завдяки освоєнню енергії пов'язаності; інакше кажучи, зв'язки можуть бути метафоризовані як джерело тієї енергії, що акумульована в спільності як характеристиці зв'язку та, відповідно, мотиваційному феномені, який проявляє себе в активності колективного суб'єкта.

Отже, спільність, яка розглядається як мотив, у своїй дієвій реалізації й постає як колективна суб'єктність. Тобто через наявність колективної суб'єктності можна судити про набуту спільність, а через специфіку колективної суб'єктності - про специфіку набутої спільності, що реалізовується в активності як мотиваційний чинник.

Висновки та перспективи подальших досліджень. Розкриття вихідних умов існування колективного суб'єкта передбачає окремий аналіз як засад колективності, так і засад суб'єктності. Якщо зосередитися спочатку на колективності та розглядати специфіку колективної суб'єктності загалом, а не щодо конкретної форми колективного суб'єкта, то специфіка колективної суб'єктності постає як творення спільності, з одного боку, і як вплив спільності - 3 другого. Подальше 3'ясування засад визначення специфіки колективної суб'єктності СВР вимагає виокремлення та означення специфіки набуття тієї або іншої спільності, а також виокремлення того процесу, результатом якого $\epsilon$ конкретний вид спільності. Власне, уже ця спроба термінологічного 
охоплення свідчить про те, що процес, у якому твориться спільність, слід було б означити як спілкування. Але таке розуміння спілкування потребує окремої розвідки, предметом якої має стати розкриття такого розуміння спілкування в контексті усталених підходів до його визначення.

\section{Список використаних джерел}

1. Татенко, В. (2017) Методологія суб'єктно-вчинкового підходу: соиіальнопсихологічний вимір. Київ: Міленіум.

2. Васютинський, В. (2005). Категорія “колективний суб' єкт” у феноменологічному дискурсі інтерсуб'єктної взаємодії. Наукові студї̈ із сочіальної та політичної психології, 12 (15), 23-37.

3. Москаленко, В. В., \& Дембицька, Н. М. (2011). Становлення суб'єкта економічної соціалізації як проблема психологічної науки. У В. В. Москаленко (Ред.), Сочіально-психологічні засади становлення суб'єкта економічної соичіалізації (с. 21-37). Київ.

4. Лукасевич, О. (2013). Суб’єкт, суб’єктність і вчинкова активність. Проблеми сучасної психологї, 1(3), 44-49.

5. Брушлинский, А., \& Воловикова, В. (Ред.). (2002). Психология индивидуального и группового субъекта. Москва.

6. Журавлев, А. (2009). Коллективный субъект: основные признаки, уровни и психологические типы. Психологический журнал, 30 (5), 72-80.

7. Гайдар, К. (2013). Социально-психологическая концепция группового субъекma. Воронеж: Изд-во Воронежского ун-та.

8. Мирошниченко, О. (2014). Методологические и методические проблемы исследования актуализации многоуровневого группового субъекта в различных социальных условиях. Научный журнал КубГАУ, 100(06). Взято из http://ej.kubagro.ru/2014/06/pdf/110.pdf.

9. Васютинський, В. (2005). Феноменологічний зміст спілкування в просторі колективного творіння дійсності. Науковий часопис НПУ імені М. П. Драгоманова. Психологічні науки. Серія 12, № 6 (30), ч. 1 с. 10-17.

10. Бублик, П., Жовтянська, В., Кальницька, Ю., Климчук, Н., Рибалка, В., Слюсаревський, М. \& Хазратова, Н. (2013). Історіографічні та методологічні координати теорій соиіальної психологї. Кіровоград: Імекс-ЛТД.

11. Горностай, П. (2012). Группа как субъект: соотношение понятий “групповая идентичность” и “идентичность группы" Психологічні перспективи. Cneціальний випуск: Актуальні проблеми психологї малих, середніх та великих груп, с. 113-121.

12. Третьяченко, В. (1997). Колективні суб'єкти управління: формування, розвиток та психологічна підготовка. Київ: Стилос.

\section{References}

1. Tatenko, V. (2017). Metodolohiia subiektno-vchynkovoho pidkhodu: sotsialnopsykholohichnyi vymir [Methodology of subjective-behavioral approach: sociopsychological dimension]. Kyiv: Milenium (ukr).

2. Vasiutynskyi, V. (2005). Katehoriia "kolektyvnyi subiekt" u fenomenolohichnomu dyskursi intersubiektnoi vzaiemodii [The category "collective subject" in the phenomenological discourse of intersubjective interaction]. Naukovi studii iz sotsialnoi ta politychnoi psykholohii, 12 (15), 23-37 (ukr). 
3. Moskalenko, V. V., \& Dembytska, N. M. (2011). Stanovlennia subiekta ekonomichnoi sotsializatsii yak problema psykholohichnoi nauky [Formation of the subject of economic socialization as a problem of psychological science]. In V.V. Moskalenko (Ed.), Sotsialno-psykholohichni zasady stanovlennia subiekta ekonomichnoi sotsializatsii (pp. 21-37). Kyiv. (ukr).

4. Lukasevych, O. (2013). Subiekt, subiektnist i vchynkova aktyvnist [Subject, subjectity and action activity]. Problemy suchasnoi psykholohii, 1(3), 44-49 (ukr).

5. Brushlinskiy, V.O., Volovikova, V. (Eds.). (2002). Psikhologiya individualnogo $i$ gruppovogo subyekta [Psychology of an individual and a group subject]. Moscow (rus).

6. Zhuravlev, A. (2009). Kollektivnyy subyekt: osnovnyye priznaki, urovni i psikhologicheskiye tipy [Collective subject: main attributes, levels and psychological types]. Psikhologicheskiy zhurnal, 30 (5), 72-80 (rus).

7. Gaydar, K. (2013). Sotsialno-psikhologicheskaya kontseptsiya gruppovogo subyekta [Socio-psychological concept of a group subject]. Voronezh (rus).

8. Miroshnichenko, O. (2014). Metodologicheskiye i metodicheskiye problemy issledovaniya aktualizatsii mnogourovnevogo gruppovogo subyekta v razlichnyikh sotsialnykh usloviyakh [Methodological and methodical issues of the research on actualization of multilevel group subject under different social conditions]. Nauchnyy zhurnal KubGAU, 100(06). Retrieved from http://ej.kubagro.ru/ 2014/06/pdf/110.pdf (rus).

9. Vasiutynskyi, V. (2005). Fenomenolohichnyi zmist spilkuvannia v prostori kolektyvnoho tvorinnia diisnosti [Phenomenological content of communication in the space of the collective creation of reality.]. Naukovyi chasopys NPU imeni M.P. drahomanova. Seriia 12. Psykholohichni nauky, 6(30), Part 1, 10-17. (ukr).

10. Bublyk, P., Zhovtianska, V., Kalnytska, Yu., Klymchuk, N., Rybalka, V., Sliusarevskyi, M. ... Khazratova, N. (2013). Istoriohrafichni ta metodolohichni koordynaty teorii sotsialnoi psykholohii [Historiographical and methodological coordinates of theories of social psychology]. Kirovohrad: Imeks-LTD (ukr).

11. Hornostai, P. (2012). Gruppa kak subyekt: sootnosheniye ponyatiy "gruppovaya identichnost" i "identichnost gruppy" [Group as a subject: the relationship between the concepts of "group identity" and "identities group"]. Psykholohichni perspektyvy. Spetsialnyi vypusk: Aktualni problemy psykholohii malykh, serednikh ta velykykh hrup, pp. 113-121 (rus).

12. Tretiachenko, V. (1997). Kolektyvni subiekty upravlinnia: formuvannia, rozvytok ta psykholohichna pidhotovka [Collective subjects of management: formation, development and psychological preparation]. Kyiv: Stylos (ukr).

(C) Коваль Г. В. 